\title{
Looking Back to the Future
}

Research Agendas for Library and Information Science

\author{
A commemorative workshop in memory of Brian Perry \\ Director of the British Library's Research and Development \\ Department 1984-1995
}

\section{Monday 27 November 2006 \\ British Library Conference Centre}

Programme | Morning session | Chair: Lynne Brindley

Coffee available from 9.30

10.15 | Introduction

Lynne Brindley

Chief Executive

British Library

10.30 | Blessed are the cheesemakers: evidence based policy versus the oral tradition Derek Law

Librarian and Head of Information Resources Directorate

University of Strathclyde

11.00 | Always look on the bright side - LIS research since 2000

Peter Brophy

Director, Centre for Research in Library \& Information Management (CERLIM)

Manchester Metropolitan University

11.30 | First breakout session

Introduction

Biddy Fisher

Head of Information Services

Sheffield Hallam University 


\section{Research needs - Short presentations from new researchers \\ in Library and Information Science}

\section{Juliet Eve}

Senior Lecturer, Division of Information and Media Studies

University of Brighton

\section{Miggie Pickton}

Academic Librarian, Information Services

University of Northampton

\section{Noeleen Schenk}

Consultant

\section{Seamus Simpson}

Principal Lecturer and Research Co-ordinator

Department of Information and Communications

Manchester Metropolitan University

12.05 I Delegates breakout into four groups - See breakout group lists

Facilitators

\section{Mel Collier}

Director of the University Library

Catholic University of Leuven

\section{Biddy Fisher}

Head of Information Services

Sheffield Hallam University

\section{Stephanie Kenna}

Manager, Regional and Library Programmes

British Library

\section{Nigel Macartney}

Director of Information Services

University of Ulster

\subsection{5 | Lunch}

\section{Programme | Afternoon session | Chair: Mel Collier}

13.45 I Research into practice; prospects for a future framework

Bob McKee

Chief Executive

Chartered Institute of Library and Information Professionals

14.30 | Second breakout session

Delegates breakout into four groups - See breakout group lists

Facilitators

As for the first breakout session 


\section{Programme | Final session | Chair: Nigel Macartney}

15.45 | Feedback from breakout session

16.15 | The way forward

Judith Elkin

Pro Vice Chancellor \& Deputy Chief Executive

University of Worcester

16.45 | Close 